\title{
MOLYBDENUM RESPONSES AT INVERMAY
}

By G. A. HOLMES, Superintendent, Invermay Research Station, Mosgiel.

After discussion with Dr E. B. Davies of the Soil Research Station about 2 years ago, the decision was made to lay down a mowing trial on secondclass undulating clay land at Invermay Agricultural Research Station, which is situated at North Taieri on the westerly side of the hills behind Dunedin. This soil has been shown to require heavy applications of lime and phosphate, but even then does not hold grass well under normal stock management. The disappearance of the better grasses is a consequence of the failure of clovers to thrive.

Analysis showed that the soil was very low in available molybdenum, containing only .04 part per million. The total molybdenum content was .91 p.p.m., or nearly 23 times the amount considered as available.

The area chosen for the trial had been sown down in the spring of 1948 under oats and had received 1 ton per acre of carbonate of lime at that time. The pasture was topdressed with $3 \mathrm{cwt}$. per acre of superphosphate in early April 1950, but showed no marked response, this being ascribed to the exceptionally dry weather experienced from February until December 1950. The ryegrass and cocksfoot appeared unthrifty, and the pasture. showed all the signs of running "out, but it still contained a good number of small Montgomery red, clover plants. This fact may have contributed to the rapidity of the results achieved.

The area was enclosed with a rabbit-proof fence, and a block of 32 plots was laid out to give 8 different treatments on a randomised plan. All the plots received a basal dressing at the rate of lcwt. per acre of serpentine superphosphate and lcwt. per acre 'of muriate of potash. 
The treatments were as follows:-

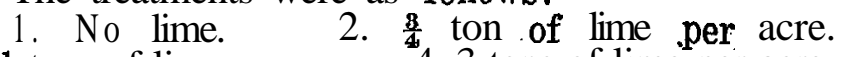
3. $1 \frac{1}{2}$ tons of lime per acre. 4.3 tons of lime per acre. $5,6,7,8$. Above, each plus $2 \frac{1}{2}$ oz per acre of sodium molybdate.

The trial was laid down on the 8th December, 1950 , received some warm rain shortly afterward, and' in less than one month showed a remarkable improvement in 16 plots treated with molybdenum. From the gateway each plot could be picked out by its darker green colour to the sharp line of. the plot, and by its more luxuriant growth of clover:

The first mowing was carried out on 11 January, 1951, using clippings returned technique, and the average green weights expressed in $1 b$. per acre were as follows :-

$\begin{array}{lcclc} & \text { No } & \mathbf{3} \text { Ton } & \text { 11 tons } & \mathbf{3} \text { tons } \\ & \text { Lime } & \text { Lime } & \text { Lime } & \text { Lime } \\ \text { Without molybdenum } & 2,813 & 3,129 & 2,715 & 4,356 \\ \text { With molybdenum } & 4,265 & 3,830 & 4,265 & 4,146\end{array}$

Differences in recovery after cutting were. very noticeable. The molybdenum-treated plots were much darker with the clovers more vigorous and more erect in growth.

A second cut was taken on 13 February 1951, and this showed an average increase of approximately 50 per cent in green herbage in favour of those plots which had received sodium. molybdate in December.

Some heavy rains were experienced in the latter half of February and during March, and as the plots were situated on slightly sloping, ground, it became evident that some of the molybdate had been washed from treated plots to untreated. plots down the slope with noticeable benefit to the clover. A third cut was taken on 28 March 1951 and showed an average increase in herbage weight- of about 43 per cent, but where an untreated plot occurred just above a treated plot on the slope the latter showed 100 per cent increase, such single-plot comparisons, of course, having no statistical value.

It may be as well to'recapitulate the special conditions obtaining for this trial:

1. It was on $\mathbf{a}$. soil reasonably well treated with phosphate and potash,. but not heavily, limed.

2. It was on a' pasture, containing a reasonable 199 
population of clover. plants, : particularly Montgomery clover (late-flowering red clover), which may be specially responsive.

3. The plots were rabbit netted, and so differences could be measured in the absence of stockgrazing selectivity.

Farmers trying molybdenum under different conditions may be disappointed or even misled.

In the 1951-52 season at Invermay pasture responses were not spectacular, owing probably to the over-growth produced by very wet weather in spring and early summer. One trial was on pasture which had received two tons, of'lime in the previous 3 years and showed a pH of 6.3.

A very marked improvement was effected in portion of a rape crop sprayed in its early stages with a solution of sodium molybdate as an observational trial.

In a replicated trial with oats the plots which had received sodium molybdate with the fertiliser could easily be distinguished in the early stages of growth by their darker green. From October to January the weather was almost continually wet, and the soil more or less waterlogged. The molybdate may have been dissolved out of the soil or translocated to the wetter portions of the plots, but whatever the reason, no consistent increase in yield resulted from the treatments.

For the 1952-53 season and later a number of trials (have been laid down. These include :

1. The effect of molybdenum on different legume species-white, subterranean, broad red and Montgomery clovers and Lotus major.

2. The interaction of molybdenum with different forms of phosphate-superphosphate, Gafsa, Nauru and Christmas Island.

3. The interaction of molybdenum with lime, phosphate, potash and some minor elements.

4. Rates of application from $1 / 160 z$. to $40 z$.

5. Times of application.

At this early stage of molybdenum investigations it may not be out of place to put forward a number of suggestions for consideration.

1. A quick and accurate method for the estimation of available molybdenum in soil samples would be of incalculable value to the Advisory officer. 
Where a soil analysis cannot readily be obtained other factors must be considered.

2. Molybdenum responses can be looked for on land originally in manuka scrub or which has reverted- to manuka, This means a very large acreage. in each island. Is. manuka then an indicator of molybdenum deficiency, a molybdenum deficient plant, or a molybdenum-efficient plant?

3. Molybdenum deficiency can be suggested as a possible cause of poor-lasting pasture on secondclass soils which have been overcropped with cereals.

4. Dr Davies has pointed out that few responses have been recorded on soils of a $\mathrm{pH}$ higher than 6.2. Farmers who have limed heavily are probably the very men who will be anxious to try molybdenum.

5. Owing to the effect of cultivation, molybdenum response may not be observable, in fact, may not be present, in newly-sown grass.

It is suggested that application be deferred until the second or third year in the life of the pasture to prevent the "slumping" so common' then on second-class soils.

6. On some soils low potash may' be a factor in. lack of response to molybdenum, and an adequate phosphate level appears essential.

7. On molybdenum-deficient soils in scrub country it is frequently noticeable that the only clover plants occur along sheep tracks or round cattle droppings. Does this arise from a concentra-, tion of molybdenum through the animal or from some effect making soil molybdenum available ?

8. Very marked effect on clover colour brought. about by earthworm activity may arise from action in the digestive tract of the worms making molybdenum into an available form.

9. Some of the magic virtues claimed for compost. and for organic fertilisers may arise either from their molybdenum content or because they render soil molybdenum available. 